Original Research Article

\title{
To evaluate the effect of neostigmine on blood glucose levels in euglycemic albino rats through OGTT
}

\author{
Suresha R. N. ${ }^{1}$, Siddamma Amoghimath ${ }^{2 *}$, Jayanthi M. K. ${ }^{1}$
}

${ }^{1}$ Department of Pharmacology, JSS Medical College and Hospital, Mysuru, Karnataka, India

${ }^{2}$ Department of Pharmacology, Gadag Institute of Medical Sciences, Gadag, Karnataka, India

Received: 08 June 2017

Revised: 01 July 2017

Accepted: 05 July 2017

*Correspondence to:

Dr. Siddamma Amoghimath,

Email: siddama.a@gmail.com

Copyright: (C) the author(s), publisher and licensee Medip Academy. This is an openaccess article distributed under the terms of the Creative Commons Attribution NonCommercial License, which permits unrestricted noncommercial use, distribution, and reproduction in any medium, provided the original work is properly cited.

\begin{abstract}
Background: Diabetes mellitus (DM) consists of a group of syndromes characterised by hyperglycaemia, altered metabolism of lipids, carbohydrates and proteins and an increased risk of complications from vascular disease. There are genetic and environmental components that affect the risk of developing either type 1 or type 2 diabetes mellitus.

Methods: Twelve Swiss albino rats weighing around 150-200gmsof either sex were randomly selected from the central animal facility, JSSMC, Mysore and divided into two groups. The control group received distilled water $(25 \mathrm{ml} / \mathrm{kg}$ body wt.) per orally, test group received Neostigmine $(0.5 \mathrm{mg} / \mathrm{kg} /$ day $)$ per orally for 5 days. On the fifth day, following overnight fasting, 1 hour after drug administration in all the group of rats OGTT was performed, by administering oral glucose in dose of $0.6 \mathrm{gm} / \mathrm{kg}$ body weight. The capillary blood glucose level was measured at 0,60 and 150 minutes, by rat tail snipping method using (ACCUCHEK) glucometer.

Results: The Capillary Blood Glucose levels of Neostigmine group was less when compared to control group at all-time intervals.

Conclusions: Neostigmine showed the hypoglycemic activity when given for 5 days orally in euglycemic albino rats through OGTT.
\end{abstract}

Keywords: Capillary blood glucose, Diabetes, Euglycemic, Neostigmine, Oral glucose tolerance test

\section{INTRODUCTION}

Diabetes mellitus (DM) consists of a group of syndromes characterized by hyperglycaemia, altered metabolism of lipids, carbohydrates and proteins and an increased risk of complications from vascular and neurological abnormalities. Most patients can be classified as having either type 1 or type 2 diabetes mellitus. There are genetic and environmental components that affect the risk of developing either type 1 or type 2 diabetes mellitus. Increased hepatic glucose output predominately accounts for increased fasting levels, whereas decreased peripheral glucose utilization results in post prandial hyperglycaemia. Type 2 diabetes is characterized by two fundamental defects: insufficient production of insulin by pancreatic $\beta$-cells and reduced target-tissue sensitivity to the effects of insulin (insulin resistance). ${ }^{1}$

In patients with Impaired Glucose Tolerance (IGT), the early-phase insulin response to glucose is reduced, and in type 2 diabetic patients, the early- phase of insulin release is both delayed and blunted. Type II DM is one of the most 
challenging health care problems, which requires optimum management. The treatment of diabetes mellitus includes insulin, sulfonylureas, biguanides, $\alpha$-glucosidase inhibitors, DPP-4 inhibitors, thiazolidinedione's, GLP-1 receptor agonists, amylin agonists, medical nutrition therapy and lifestyle modification. ${ }^{2}$

\section{Insulin release}

Glucose gets phosphorylated by glucokinase to glucose 6 phosphate, which enters the glycolytic pathway, producing NADPH and increased ratio of ATP/ADP. Elevated ATP/ADP inhibits ATP sensitive $\mathrm{K}^{+}$channel leading to depolarization. The ATP sensitive $\mathrm{K}+$ channel consists of (kir6.2) inward rectifying channel and a closely related (SUR) sulfonylurea receptor. The closure of K-ATP channel depolarizes the cell membrane to potentials above $-55 \mathrm{mV}$. Activation of T-type (at voltages above $-60 \mathrm{mV}$ ) and L-type $\mathrm{Ca}^{2+}$ channels (above $-50 \mathrm{mV}$ ) initiates the action potential. During the upstroke of the action potential, voltage-gated $\mathrm{Na}^{+}$channels also open (above $-40 \mathrm{mV}$ ), leading to a further acceleration of the upstroke and sufficient depolarization to activate $\mathrm{P} / \mathrm{Q}$ type $\mathrm{Ca}^{2+}$ channels (above $-20 \mathrm{mV}$ ). $\mathrm{Ca}^{2+}$ influx via $\mathrm{P} / \mathrm{Q}-$ type (and to a lesser extent L-type) directly triggers exocytosis of insulin granules. $\mathrm{Na}^{+}$current is important for glucose-induced insulin secretion, the significance of these channels for action potential generation and insulin secretion.

Voltage-gated plasmalemmal ion channels play a fundamental role in stimulus secretion coupling in cells, and $\mathrm{Ca}^{2+}$ influx through voltage-gated $\mathrm{Ca}^{2+}$ channels triggers exocytosis of insulin containing secretory granules. Voltage-gated $\mathrm{Ca}^{2+}$ channels are activated by coordinated fluctuations of the cell membrane potential (electrical activity), which are initiated by the glucoseinduced closure of ATP-sensitive $\mathrm{K}^{+}$channels (KATP channels) and dependent on voltage- gated $\mathrm{Na}^{+}$and $\mathrm{K}^{+}$ channels. $^{3}$

\section{Oral Glucose Tolerance Test (OGTT)}

The oral glucose tolerance test is a measure of the glucose induced insulin secretion and its mediated glycemic changes. This study used OGTT for normoglycemic rats with some modifications to the standard method (Duvigneaud and Karr, 1925) to assess the effect of Neostigmine on glucose induced glycemic alteration. ${ }^{4}$

Neostigmine is used in the treatment of myasthenia gravis, reversal of non- depolarizing muscle relaxants and routinely in anaesthesia to reverse the effects of nondepolarizing muscle relaxants such as rocuronium and vecuronium at the end of an operation, Ogilvie syndrome which is a pseudo obstruction of the colon in critically ill patients, for urinary retention resulting from general anaesthesia and to treat curare form drug toxicity, to delay the effects of envenomation through snakebite. ${ }^{5}$
The acetylcholine/ vagus effects on pancreatic insulin release are mediated by activation of muscarinic acetylcholine receptors located on the pancreatic $\beta$-cells. M3 receptors are present in visceral smooth muscles, iris, ciliary muscle, exocrine glands, endocrine glands and vascular endothelium. ${ }^{6}$ They are $\mathrm{G}_{\mathrm{q}}$ - protein coupled and activate the membrane bound phospholipase (PLC) generating inositol triphosphate (IP3) and diacylglycerol (DAG) which in turn release $\mathrm{Ca}^{2+}$ intracellularly causing depolarization

Neostigmine is an anticholinesterase which inhibits metabolism of acetylcholine by acetyl cholinesterase thereby enhancing its cholinergic effects facilitating impulses across myoneural junction. ${ }^{7}$ Neostigmine has half-life of 50-60 minutes and Neostigmine is metabolized in the liver by microsomal enzymes. Neostigmine is eliminated through urine. ${ }^{8}$

The sequential events are depicted in the Figure 1.

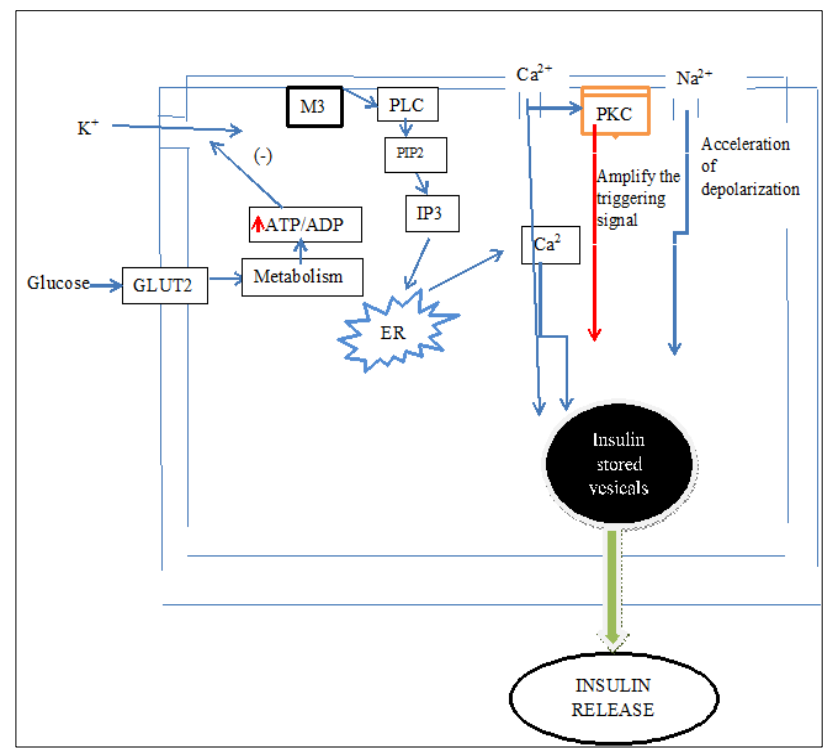

M3: Muscarinic M3 Receptors; PLC:-Phospholipase C; PIP2:-Phosphatidylinositol 4, 5- bisphosphate; IP3:Inositol triphosphate; ER:-Endoplasmic reticulum; DAG: -Diacyl glycerol; PKC: - Phosphokinase C.

Figure 1: The above figure shows the schematic representation of mechanism of action of insulin release through muscarinic receptors (M3) on pancreatic $\beta$ cell.

Thus, the mechanism, by which anti cholinesterase acts to cause insulin secretion is:

- $\quad$ Major pathways are activation of PLC, which mainly generates IP3 and diacylglycerol, a potent PKC activator.

- Acetylcholine also depolarizes the plasma membrane of $\beta$ cells by a $\mathrm{Na}^{+}$or nonspecific cationic-dependent mechanism. 


\section{Hypothesis}

Acetylcholine acting through M3 receptors, by activation of phospholipase $\mathrm{C}$ generates IP3 and diacylglycerol. It also depolarizes the membrane of insulin stored granules by sodium channel and causes secretion of insulin leading to decrease in blood glucose. Neostigmine an anticholinesterase is hypothesized to exhibit the same activity.

\section{METHODS}

Albino rats of either sex of average weight 150-200gms aged 3-4 months were used in experiments. The albino rats were bred in Central Animal Facility of JSS Medical College, Mysore. The study was done in department of pharmacology during the month of March 2014. Animals were acclimatized to the laboratory conditions for at least 1 hour before testing and then they were used during experiments. The doses of drugs were based on the human daily dose converted to that of animal dose using the standard formula. ${ }^{9}$

\section{Drugs and chemicals}

Tab. Neostigmine 15mg (Abbott Healthcare Pvt. Ltd, India) was dissolved in distilled water and immediately administered orally, distilled water given orally, $0.6 \mathrm{mg} / \mathrm{kg}$ of glucose mixed in distilled water for OGTT.

\section{Methodology}

The rats were divided into 2 groups containing 6 animals $(n=6)$ in each group (control and test group). The test drug Neostigmine $0.5 \mathrm{mg} / \mathrm{kg} / \mathrm{day}$ and distilled water $25 \mathrm{ml} / \mathrm{kg}$ /day was administered orally for 5 days.

- Group 1: Distilled water- $25 \mathrm{ml} / \mathrm{kg} /$ day (orally)

- Group 2: Neostigmine $0.5 \mathrm{mg} / \mathrm{kg} /$ day (orally)

All rats were fasted overnight before the 5th day. On the $5^{\text {th }}$ day 1 hour after the last dose of the respective drug, OGTT was performed. All the rats were given glucose $(0.6 \mathrm{gm} / \mathrm{kg}$ body weight) orally using gavage tube. Following this, the Capillary blood glucose (obtained by tail snipping) was assessed at 0,60 , and 150 minutes of time intervals using a glucometer (ACCUCHEK).

\section{RESULTS}

The mean capillary blood glucose of control group is $73.16 \mathrm{mg} / \mathrm{dl}, 100.33 \mathrm{mg} / \mathrm{dl}$ and $82 \mathrm{mg} / \mathrm{dl}$ while in that of neostigmine group is $64.5 \mathrm{mg} / \mathrm{dl}, 86.33 \mathrm{mg} / \mathrm{dl}$ and $72.66 \mathrm{mg} / \mathrm{dl}$ at $0 \mathrm{~min}, 60 \mathrm{~min}$, and $150 \mathrm{~min}$ respectively. The fall in the CBG levels in the neostigmine group when compared to the control group is $8.66 \mathrm{mg} / \mathrm{dl}$ at $0 \mathrm{~min}$, $14 \mathrm{mg} / \mathrm{dl}$ at $60 \mathrm{~min}$ and $9.34 \mathrm{mg} / \mathrm{dl}$ at $150 \mathrm{~min}$, with maximum fall at $60 \mathrm{~min}$. The fall in CBG levels of Neostigmine group was statistically significant $(\mathrm{p}<0.05)$ at $0 \mathrm{~min}, 60 \mathrm{~min}$ and $150 \mathrm{~min}$ (Table 1).
Table 1: Capillary Blood glucose (CBG) levels in control, and Neostigmine group and the difference between the control and Neostigmine group at corresponding time intervals.

\begin{tabular}{|llll|}
$\begin{array}{l}\text { Time } \\
\text { interval } \\
\text { during } \\
\text { OGTT }\end{array}$ & $\begin{array}{l}\text { Control } \\
\text { group } \\
\mathbf{N}=6\end{array}$ & $\begin{array}{l}\text { Ceostigmine } \\
\text { group } \\
\mathbf{N}=6\end{array}$ & $\begin{array}{l}\text { Fall in CBG } \\
\text { levels } \\
\text { Neostigmine } \\
\text { group compared } \\
\text { to control group }\end{array}$ \\
\hline 0 min & $73.16 \pm 4.87$ & $64.5 \pm 1.87^{*}$ & $8.66 \pm 3$ \\
\hline 60 min & $100.33 \pm 3.55$ & $86.33 \pm 2.16^{* *}$ & $14 \pm 1.39$ \\
\hline 150 min & $82 \pm 4.19$ & $72.66 \pm 4.45^{*}$ & $9.34 \pm 0.26$ \\
\hline $\begin{array}{l}\text { Data is expressed as } \\
\text { p }<0.01 \text { compared with control (distilled water). SD: Standard }\end{array}$ \\
$\begin{array}{l}\text { Deviation } \\
\text { ment }\end{array}$
\end{tabular}

The percentage fall in Capillary Blood glucose (CBG) level in Neostigmine group when compared to control is $11.83 \%, 13.95 \%$ and $11.39 \%$ at $0 \mathrm{~min}, 60 \mathrm{~min}$ and $150 \mathrm{~min}$ (Table 2).

Table 2: Percentage fall in Capillary Blood glucose (CBG) level in Neostigmine group when compared to control.

\begin{tabular}{|lll|l|}
\hline Sr. no. & $\mathbf{0} \mathbf{~ m i n}$ & $\mathbf{6 0} \mathbf{~ m i n}$ & $\mathbf{1 5 0} \mathbf{~ m i n}$ \\
\hline Neostigmine & 11.83 & 13.95 & 11.39 \\
\hline
\end{tabular}

The inter interval difference of control at $0-60 \mathrm{~min}$ is $27.17 \mathrm{mg} / \mathrm{dl}$, at $60-150 \mathrm{~min}$ is $18.33 \mathrm{mg} / \mathrm{dl}$ and at $0-150 \mathrm{~min}$ is $8.84 \mathrm{mg} / \mathrm{dl}$. The inter interval difference of neostigmine group at $0-60 \mathrm{~min}$ is $21.83 \mathrm{mg} / \mathrm{dl}$, at $60-150 \mathrm{~min}$ is $13.67 \mathrm{mg} / \mathrm{dl}$ and at $0-150 \mathrm{~min}$ is $8.16 \mathrm{mg} / \mathrm{dl}$. Thus, the CBG levels inter interval differences of neostigmine group is lower when compared to control and is statistically significant $(\mathrm{p}<0.05)$ (Table 3).

Table 3: The difference in the CBG levels of Neostigmine and control group at time intervals 0 min, $60 \mathrm{~min}$ and $150 \mathrm{~min}$ of OGTT.

\begin{tabular}{|lll|}
\hline Time interval & \multicolumn{2}{l|}{ Change in CBG values } \\
\hline C-60 min & $27.17 \pm 1.32$ & $21.83 \pm 0.2 *^{*}$ \\
\hline $60-150 \mathrm{~min}$ & $18.33 \pm 0.64$ & $13.67 \pm 2.29^{*}$ \\
\hline $0-150 \mathrm{~min}$ & $8.84 \pm 0.68$ & $8.16 \pm 2.58^{*}$ \\
\hline
\end{tabular}

Data is expressed as $\mathrm{mg} / \mathrm{dl}$, ${ }^{\mathrm{p}}<0.05$ compared with control (distilled water)

The difference in CBG levels between control group and Neostigmine group at various time intervals, at $0-0 \mathrm{~min}$ is $8.66 \mathrm{mg} / \mathrm{dl}$, at $0-60 \mathrm{~min}$ is $13.17 \mathrm{mg} / \mathrm{dl}$, at $0-150 \mathrm{~min}$ is $0.5 \mathrm{mg} / \mathrm{dl}$, at $60-0 \mathrm{~min}$ is $35.83 \mathrm{mg} / \mathrm{dl}$, at $60-60 \mathrm{~min}$ is $14 \mathrm{mg} / \mathrm{dl}$, at $60-150 \mathrm{~min}$ is $27.67 \mathrm{mg} / \mathrm{dl}$, at $150-0 \mathrm{~min}$ is $17.5 \mathrm{mg} / \mathrm{dl}$, at $150-60 \mathrm{~min}$ is $4.33 \mathrm{mg} / \mathrm{dl}$, at $150-150 \mathrm{~min}$ is $9.34 \mathrm{mg} / \mathrm{dl}$ (Table 4). 


\section{Table 4: Depicts difference in CBG values between control group and Neostigmine group at various time intervals.}

\begin{tabular}{|ll|}
\hline $\begin{array}{l}\text { OGTT time interval of } \\
\text { Control - OGTT time interval } \\
\text { of Neostigmine }(\mathrm{C}-\mathrm{T})\end{array}$ & $\begin{array}{l}\text { Difference in CBG } \\
\text { values }(\mathrm{mg} / \mathrm{dl})\end{array}$ \\
\hline $0-0 \mathrm{~min}$ & $8.66^{*}$ \\
\hline $0-60 \mathrm{~min}$ & $13.17^{*}$ \\
\hline $0-150 \mathrm{~min}$ & $0.5 *$ \\
\hline $60-0 \mathrm{~min}$ & $35.83^{*}$ \\
\hline $60-60 \mathrm{~min}$ & $14^{*}$ \\
\hline $60-150 \mathrm{~min}$ & $27.67^{*}$ \\
\hline $150-0 \mathrm{~min}$ & $17.5 *$ \\
\hline $150-60 \mathrm{~min}$ & $4.33^{*}$ \\
\hline $150-150 \mathrm{~min}$ & $9.34^{*}$ \\
\hline
\end{tabular}

Data is expressed as $\mathrm{mg} / \mathrm{dl},{ }^{*} \mathrm{p}<0.05$ compared with control (distilled water)

\section{DISCUSSION}

In normal individuals, the insulin release from $\beta$ cells through the early phase begins within minutes of a glycemic stimulus. Early-phase insulin primes tissues that are sensitive to it, in particular liver, which results in the reduction of hepatic glucose output. Type 2 diabetes is characterized by insufficient insulin secretion by pancreatic $\beta$ cells and reduced peripheral sensitivity to the effects of insulin (insulin resistance). In type 2 diabetic patients the important defect in insulin secretion is the impairment of early-phase insulin release which is both delayed and blunted. ${ }^{10}$

In patients with IGT, the early-phase insulin response to glucose is reduced. In isolated IGT, basal insulin secretion is normal but glucose-stimulated first- and second-phase insulin secretion and (peripheral) insulin sensitivity is reduced. The loss of early-phase insulin release during and after the prandial phase has several deleterious effects on normal glucose homeostasis: hepatic glycogenolysis and gluconeogenesis are not inhibited sufficiently, and glucose uptake by muscle is insufficient. This leads to the postprandial hyperglycemia observed in glucoseintolerant and type 2 diabetic patients. In isolated IFG, basal insulin secretion and glucose-stimulated first-phase insulin secretion are impaired but second-phase insulin secretion and (peripheral, mainly representing muscle) insulin sensitivity are normal.

In pancreatic $\beta$ ells, glucose stimulates insulin secretion by generating triggering and amplifying signals. The triggering pathway is well characterized. It involves the following sequence of events: entry of glucose by facilitated diffusion, metabolism of glucose by oxidative glycolysis, rise in the ATP-to-ADP ratio, closure of ATPsensitive $\mathrm{K}+(\mathrm{KATP})$ channels, membrane depolarization, opening of voltage-operated $\mathrm{Ca}^{2+}$ channels, $\mathrm{Ca}^{2+}$ influx, rise in cytoplasmic free $\mathrm{Ca}^{2+}$ concentration $\left[\mathrm{Ca}^{2+}\right] \mathrm{i}$, and activation of the exocytotic machinery. Under these conditions, glucose still increases insulin secretion in a concentration-dependent manner. This increase in secretion is highly sensitive to glucose (produced by as little as 1-6 mmol/ 1 glucose), requires glucose metabolism, is independent of activation of protein kinases $\mathrm{A}$ and $\mathrm{C}$, and does not seem to implicate long-chain acyl-CoAs. Changes in adenine nucleotides may be involved. The amplification consists of an increase in efficacy of $\mathrm{Ca}^{2+}$ on exocytosis of insulin granules. There exists a clear hierarchy between both pathways. The triggering pathway predominates over the amplifying pathway, which remains functionally silent as long as $\left[\mathrm{Ca}^{2+}\right] \mathrm{i}$ has not been raised by the first pathway; i.e., as long as glucose has not reached its threshold concentration. The amplifying pathway serves to optimize the secretory response not only to glucose but also to non-glucose (amino acids) stimuli. It is impaired in $\beta$-cells of Type 2 diabetic patients. Besides the available drugs that act on $\mathrm{K}^{+} \mathrm{ATP}$ channels and increase the triggering signal, novel drugs that correct a deficient amplifying pathway would be useful to restore adequate insulin secretion in type 2 diabetic patients. ${ }^{11,12}$

OGTT is an established method to prove the intactness of $\beta$ cells and influence of glucose on, glucose stimulated insulin secretion which is depicted at periphery by variation of glycemic levels in the blood. ${ }^{13}$

Thus, the findings indicate that Neostigmine acts as a hypoglycemic drug in normal albino rats. OGTT test is used to assess the glucose tolerance which indirectly indicates the insulin sensitivity and beta cell function. Hence, in diabetics and pre-diabetics it can be assumed that Neostigmine causes decreased in blood glucose levels.

\section{CONCLUSION}

The test drug Neostigmine showed significant decrease in capillary blood glucose level in euglycemic albino rats when compared to that of control through OGTT. The hypoglycemic activity of Neostigmine was maximum during the $60 \mathrm{~min}$, which justifies the hypothesis stated above and enhances the glucose dependent insulin release.

Thus, to conclude Neostigmine causes decrease in blood glucose levels in euglycemic albino rats through muscarinic receptor stimulation, through activation of phospholipase C generates IP3 and diacylglycerol and also depolarizes membrane by sodium channel and causes secretion of insulin. Therefore, decrease in blood glucose.

\section{ACKNOWLEDGEMENTS}

Authors would like to thank the institution for permitting and providing the necessary assistance for the study.

Funding: No funding sources

Conflict of interest: None declared

Ethical approval: The study was approved by the Institutional Animal Ethics Committee (JSSMC/IAEC/12/5655/DEC 2013) 


\section{REFERENCES}

1. Abbruzzese JL, Aboulhosn J, Achermann JC, Powers AC, James P. Diabetes mellitus. In Dan L. Longo, Dennis L. Kasper, editors. Harrison's princples of internal medicine. New York: Mcgraw- hill; 2013:2276-2279.

2. Nicholson G, Hall GM. Diabetes mellitus: new drugs for a new epidemic. British Journal of Anaesthesia. 2011;107(1):65-73.

3. Braun M, Ramracheya R, Bengtsson M. VoltageGated Ion Channels in Human Pancreatic $\beta$ Cells: Electrophysiological Characterization and Role in Insulin Secretion. Oxford Centre for Diabetes Endocrinology and Metabolism. Diabetes. 2008;57:1622-7.

4. Breda E, Cavaghan MK, Toffolo G, Polonsky KS, Cobelli C. Oral glucose Tolerance Test minimal Model Indexes of $\beta$-cell Function and Insulin Sensitivity. Diabetes. 2001;50:150-8.

5. Hilal-Dandan R. Muscarinic receptor agonist and antagonist. In: Bruton LL, editor. Goodman and Gilman's the Pharmacological Basis of Therapeutics. $12^{\text {th }}$ Ed. China: McGraw Hill; 2011:311-25.

6. Gautam D, Han SJ, Duttaroy A, Mears D, Hamdan FF, Li JH, et al. Role of the M3 muscarinic acetylcholine receptor in $\beta$-cell function and glucose homeostasis. Diabetes, Obesity and Metabolism. 2007 Nov 1;9(s2):158-69.

7. Billups D, Billups B, Challiss RJ, Nahorski SR. Modulation of Gq-protein-coupled inositol trisphosphate and $\mathrm{Ca} 2+$ signaling by the membrane potential. Journal of Neuroscience. 2006 Sep 27;26(39):9983-95.

8. Tripathi KD. Cholinergic system and drugs. In: KD Tripathi. Essentials of medical pharmacology. New Delhi: Jaypee; 2013:105-112.

9. Medhi B, Prakash A. Introduction to experimental pharmacology. In: Bikash Medhi, editors. Practical manual of experimental and clinical pharmacology. New Delhi: Jaypee; 2010:.23-25.

10. Tuomilehto J. Point: a glucose tolerance test is important for clinical practice. Diabetes Care. 2002;25:1880-2.

11. Jean-Claude H. Triggering and Amplifying Pathways of Regulation of Insulin Secretion by Glucose. Diabetes. 2000 November 49:1751-60.

12. Komatsu M, Sato Y, Yamada S, Yamauchi K, Hashizume K, Aizawa T. Triggering of insulin release by a combination of cAMP signal and nutrients. Diabetes. 2002 Feb 1;51(1):S29-32.

13. Meier JJ, Menge BA, Breuer TGK, Mu"ller CA, Tannapfel A, Uhl W. Functional Assessment of Pancreatic Cell Area in Humans. Diabetes. 2009 July 58:1595-603.

Cite this article as: Suresha RN, Amoghimath S, Jayanthi MK. To evaluate the effect of neostigmine on blood glucose levels in euglycemic albino rats through OGTT. Int J Basic Clin Pharmacol 2017;6:2038-42. 